\title{
The Effectiveness of Mobile Learning Based Android in Learning English Vocabularies
}

\author{
https://doi.org/10.3991/ijim.v13i12.11167 \\ Iriany Kesuma Wijaya $\left({ }^{\bowtie}\right)$, Rina Asrini Bakri, Antonius Ali Wutun, \\ Fitriani, Achsan Andi Mattoliang \\ STKIP YPUP Makassar, Sulawesi Selatan, Indonesia \\ irianykesuma08@gmail.com
}

\begin{abstract}
This research aims to examine the effectiveness of android-based mobile learning in learning vocabulary among SMP Batara Gowa's seventh grade students. Pre-experimental research design was used, namely one group pre-test post-test design. The populations in this study were all seventh-grade students of SMP Batara Gowa, and the sample was class VII.1 as the experimental class, which was chosen by using purposive sampling. The results of the data analysis show that the mean score of post-test (70.55) was higher than the mean score of pre-test (34.65). The result of the t-test was 30.117 and t-table 2.093. It could be indicated that the null hypothesis (H0) was rejected and the alternative hypothesis (H1) was accepted. Based on the effectiveness criteria, generally using mobile learning based android was effective in learning vocabulary at the seventh-grade students of SMP Batara Gowa.
\end{abstract}

Keywords—Mobile learning, Students' Vocabulary, Android

\section{Introduction}

The rapid development of technology in the current era of globalization has provided many benefits in the advancement in various aspects of life. The use of technology by humans in helping to accomplish work is a must in life.

Human adaptation to emerging technologies is mandatory for education. It is accomplished so that the next generation is not left behind in terms of technology. Therefore, technology and education can grow together. The technology has a significant impact on education [1].

Along with technological developments that progress, the most rapid development is in the use of mobile devices based android. The use of mobile devices based Android is currently increasing. Nowadays, mobile devices are gaining popularity. Learning mobile language textbooks can help students with their studies dramatically [2]. However, in the Indonesian context, mobile devices are generally only used for phones, messages chats, games, and other entertainment.

The use of mobile devices in learning, especially in learning English is still lacking even though English is an international language associated with many aspects. Almost all aspects of education, technology and others use English as a medium to 
communicate. In learning English, we need to know the vocabulary, where vocabulary mastery plays an essential role in learning English. Therefore, it is designed a smartphone app named as Word Learning-CET6. After designing, he examined this application and found that the students using this program significantly outperformed in acquiring new vocabulary [3]. One of the advantages of using the application in learning is that the students can learn anytime and [4].

Mastery of English, when enhanced by mastering a good vocabulary, will affect the skills of a person in the language. Having sufficient vocabulary is one of the requirements to master English. As has been said before, Mastering vocabulary is one of the most important things to master in English learning. The more vocabulary in mastered English, the easier it will be to learn and understand the foreign language. In general, learners who are merely starting to learn English desperately need a good vocabulary and adequate, and then learners will be able to understand the purpose of the English language.

Vocabulary is one of the language elements that play an essential role in the understanding passage and communicating ideas, emotions, feelings, and thoughts in both oral and written form. Vocabulary is a primary basis for constructing the ability of speaking, writing, listening, and reading. Without the mastering vocabulary, the students cannot communicate their ideas, emotions, thoughts and desires because vocabulary is essential for understanding the meaning of words. Having a wide range of knowledge of structure or competence of every English skill is not enough if our vocabulary is supposed a crucial requirement in studying English.

Emphasizing the importance of vocabulary, we are always going to be concerned about language abilities. Therefore, it is impossible to separate vocabulary from four language skills: listening, speaking reading and writing. In order to clarify this, let us consider the importance of language skills.

Vocabulary is used to understand the speech of someone or what people do. It is difficult for us to understand what someone else says if the students know the sentence's structure without knowing the words. There is empirical evidence that listening skills include vocabulary [5]. Vocabulary is used in speaking to verbally transmit our thoughts or feelings to others. The terms we have been familiar with affect effective communication. In reading, the vocabulary is used in learning to grasp the reading material. Learning without vocabulary skills can make a text hard to understand. The number of words that someone knows and the meaning of words can influence their reading performance. It is not impossible to understand the sentence unless he/she knows the meaning of the words used in the message. The frequency of the vocabulary and the scope of the vocabulary have a positive impact on the quality of EFL learning [6]. In writing, the author's vocabulary (words) was used to develop his concept an author should choose the words to express his / her idea clearly and accurately. We cannot improve our writing without knowing a lot of vocabulary, because we are limited in vocabulary mastering.

English learners and English teachers must consider vocabulary as one of the critical components of writing since learning a language often require first learning the language itself. The lack of vocabulary sometimes makes somebody fail to compose what they are going to say because they face the difficulties of choosing the most 
suitable words equivalent to Indonesian words. It is now clear that if we lack vocabulary, we cannot write or communicate our thoughts. Therefore, without having many words, we cannot grasp the reading passage.

It is believed that learners can identify and understand the context of reading and listening content through acquiring vocabulary, and then as productively as learners can remember and use it correctly in speech and writing [7]. In this case, the statement noted by [8] that through mastering vocabulary learners can understand all words in both written and oral forms and eventually utilize them every day in speech and writing.

From the results of observations at the 7th-grade students of SMP, Batara Gowa researcher found that there are some problems in English learning process that is students' lack of understanding in terms of vocabulary and pronunciation and lack of learning aids. This case makes the students have low achievement in learning English. However, not all students' experience it because each student has different abilities. To solve this problem, an English teacher should be creative to choose appropriate ways to be teaching. The English teacher should be pushed to find a way to inspire students to learn vocabulary. The use of mobile devices in learning is one of the efforts to create a more meaningful and useful learning process.

Given the development of advanced science and technology, the demand to be able to master a foreign language as a communication tool is a necessity. Thus, the process of learning English can be understood easily by everyone if it can maximize learning environment included in the case of learning aids.

Mobile learning is learning by utilizing mobile devices. Mobile learning can contain different learning because learning is done using a smartphone. Mobile learning itself becomes a new paradigm in the world of learning. Learning strategy is present to respond to the rapid development of information and communication technology world lately. Mobile learning can be used as an alternative to solve problems in the field of education, especially the problem of equitable access to education information.

We know that learning today is not just in the classroom, learning only by utilizing whiteboards and markers, but learning can also be done using a smartphone. For example android as an operating system of mobile devices that can be useful in mobile learning or flexible learning to learn anywhere and anytime

Mobile learning applications are one of the mobile devices that can be obtained by using an Android operating system. Android provides developers with an open platform to build their apps that mobile devices can use. Researchers will use the Android operating system to design this English vocabulary application.

The findings of this work are required to contribute to the learning process theoretically and practically. Theoretically, the researcher hopes that applying mobile learning in the learning process can be effective because this strategy is more fun and enjoyable.

Based on the above description, the researchers are interested to conduct a research entitled "The Effectiveness of Mobile Learning Based Android in Learning Vocabulary at the Seventh Grade Students of SMP Batara Gowa". This research aims at find- 
ing out whether mobile learning based android is effective in learning vocabulary at the 7th-grade students of SMP Batara Gowa.

\subsection{Conceptual Framework}

The theoretical framework of this research that is served can be seen in the following figure.

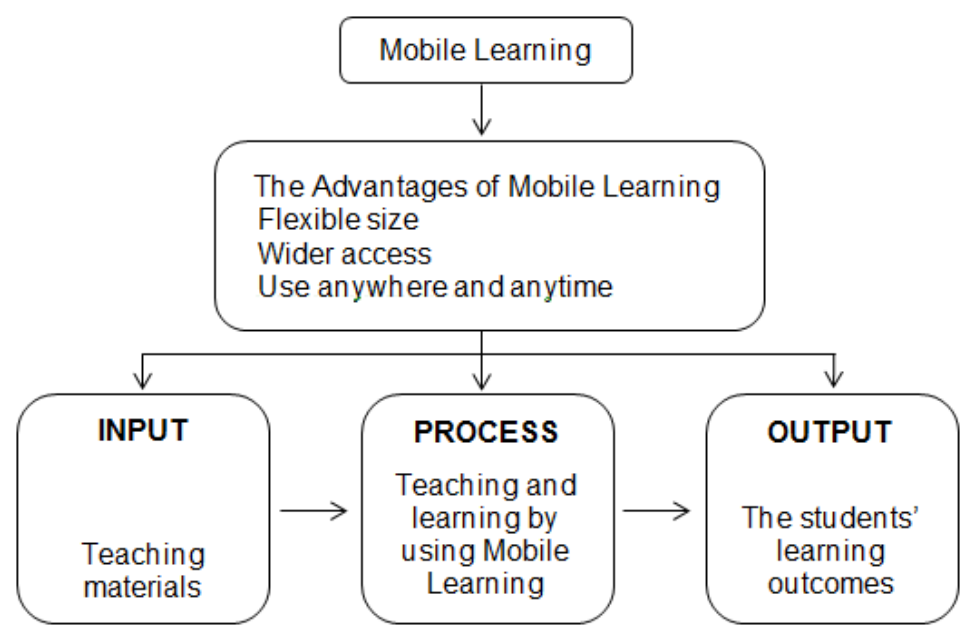

Fig. 1. Conceptual Framework

\subsection{Hypothesis}

There are two research hypothesis proposed in this study.

H_0: The use of mobile learning is not effective for 7th-grade students' in increasing vocabulary mastery at SMP Batara Gowa

H_ 1: The use of mobile learning is effective for 7th-grade students' in increasing vocabulary mastery at SMP Batara Gowa

\section{Methods}

The research method used was pre-experimental. This research consisted of three steps, namely, pre-test, treatment, and post-test. This study consisted of one class with the same treatment, namely the using of mobile learning based android. It aims to determine the effectiveness of using mobile learning in teaching vocabulary in SMP Batara Gowa. The design of this research is presented as follow.

$01 \times 02$

01 : Pre-test

$\mathrm{X} \quad$ : Treatment

02 : Post-test [9] 
There were two variables in this study. They were the dependent and independent variable. Independent variable was mobile learning, and the dependent variable was students' ability in vocabulary.

The population of this research was the 7th-grade students of SMP Batara Gowa in 2018/2019 academic year, and there were two classes, each class consisted of 20 and 23 students. Therefore, the total number of population was 43 students. The purposive sampling technique was used in selecting research samples. The class 7 th one was chosen as a sample which consisted of 20 students. This class was chosen because the ability of students in vocabulary was still low.

The researcher used the vocabulary test as an instrument. The vocabulary test was used to determine students' vocabulary skills, in this case, the researcher gave the test on matching each word, wrote down the meaning of each word as well as answering multiple-choice questions, both pre-test and post-test.

In collecting data, there were three steps applied by the researcher in the class. The first was giving the pre-test to the students and then carrying out the treatment, and the last was conducting the post-test. The researchers used statistical analysis and IBM SPSS statistics 20 version to know the students' achievement both of ten groups.

\section{Results}

The findings of the research deal with the frequency and rate percentage of the students' score in pre-test and post-test, the mean scores of pre-test and post-test, standard deviation, the t-test value and the hypothesis testing.

The researcher collected the data through mobile learning application, both pre-test and post-test, where pre-test was given before the students having treatments and post-test was given after having treatments. The pre-test was given in the first meeting before giving any treatments. Pre-test and post-test were one day each, then treatment six days, so the entire meeting of this research was eight meetings.

\subsection{The result of pre-test and post-test}

A test was performed by the researchers to find out the answer to the research question the test is conducted twice. Before the treatment, the pre-test was given, which aims to know the prior knowledge of English vocabulary of the students. The post-test was also given to determine the outcome of the treatment.

The pre-test was given before the students have had treatments. It aimed at finding out the students' vocabulary prior knowledge. The order of this test was based on vocabulary purpose. The purpose here means that the students' vocabulary acquisition. Before they worked out the test given, the researcher explained clearly how to answer the questions. In this test, the researcher found that some students had some difficulties in answering the questions provided. 
Table 1. Frequency and the rate percentage of the students' score in pre-test

\begin{tabular}{|c|l|c|c|c|}
\hline No & \multicolumn{1}{|c|}{ Classification } & Score & Frequency & Percentage \\
\hline 1. & Very Good & $91-100$ & 0 & $0 \%$ \\
\hline 2. & Good & $76-90$ & 0 & $0 \%$ \\
\hline 3. & Fair & $61-75$ & 0 & $0 \%$ \\
\hline 4. & Poor & $51-60$ & 3 & $15 \%$ \\
\hline 5. & Very Poor & $0-50$ & 17 & $85 \%$ \\
\hline Total & & 20 & $100 \%$ \\
\hline
\end{tabular}

No students got a very good, good, and fair classification based on the data in the table above, but there were three students $(15 \%)$ with poor classification, and there were 17 students $(85 \%)$ with a very poor classification. From the above result, it can be seen and inferred that in their English vocabulary, many students were very weak. Their vocabulary is still limited.

To measure the students understanding about the material given and the effectiveness of this strategy, the researcher prepared the second test that is post-test. It aimed at finding out the students' vocabulary increase after the students have been learned vocabulary by using mobile learning.

Table 2. Frequency and the rate percentage of the students' score in post-test

\begin{tabular}{|c|l|c|c|c|}
\hline No & \multicolumn{1}{|c|}{ Classification } & Score & Frequency & Percentage \\
\hline 1. & Very Good & $91-100$ & 0 & $0 \%$ \\
\hline 2. & Good & $76-90$ & 7 & $35 \%$ \\
\hline 3. & Fair & $61-75$ & 9 & $45 \%$ \\
\hline 4. & Poor & $51-60$ & 2 & $10 \%$ \\
\hline 5. & Very Poor & $0-50$ & 2 & $10 \%$ \\
\hline Total & & 20 & $100 \%$ \\
\hline
\end{tabular}

The table above shows that after giving treatments to the students through mobile learning, there was significant difference result of the students' works in the vocabulary test. There were seven students $(35 \%)$ got good classification, there were nine students $(45 \%)$ got fair classification, there were two students $(10 \%)$ got poor classification, and two students (10\%) got the very poor classification. It means that the majority of the students shown their increase in English vocabulary after giving treatments.

Table 3. Class and Mean Score

\begin{tabular}{|l|c|}
\hline \multicolumn{1}{|c|}{ Class } & Mean Score \\
\hline Pre-test & 34.65 \\
\hline Post-test & 70.55 \\
\hline
\end{tabular}

The data on the table above shows that the mean score of students' pre-test was 34.65 which classified as very poor, while the mean score of students' post-test was 70.55 which classified as the fair was higher than the mean score of the students' pretest. It means that with the effectiveness of using a mobile learning strategy, it can 
increase to the mastery of English vocabulary for seventh-grade students of SMP Batara Gowa.

\subsection{T-Test value}

The using of t-test in this research was to know the students' significant difference in students' vocabulary mastery after treatment by using mobile learning.

Table 4. T-Test and T-Table

\begin{tabular}{|c|c|c|}
\hline Variable & T-Test & T-Table \\
\hline $\mathrm{X}_{2}-\mathrm{X}_{1}$ & 30.117 & 2.093 \\
\hline
\end{tabular}

Table 4 above shows that t-table was smaller than the t-test value of the students' English vocabulary where the value of t-test was 30.117 and t-table was 2.093. Thus, the value of t-test was more significant than the t-table value $(30.117>2.093)$. It means that the effectiveness of using mobile learning can significantly increase the English vocabulary of seventh-grade students of SMP Batara Gowa. Thus, this research supported (H1), there was a significant improvement in the students' vocabulary achievement before and after teaching by using mobile learning.

It is supported by the rate percentage result of the students' pre-test and post-test from "very poor" to "good" degree. Based on the results of the t-test, the researchers found that there was a significant difference between the pre-test and post-test score. It means that the test before and after vocabulary teaching and learning through mobile learning shows a significant result.

\subsection{Hypothesis testing}

After calculating the data by using a t-test, than to find out the degree of freedom (df), the researcher used the following formula.

$$
\begin{aligned}
& \mathrm{df}=\mathrm{N}-1 \\
& \mathrm{df}=20-1 \\
& \mathrm{df}=19
\end{aligned}
$$

For the level significant $(P)=0.005$, the degree of freedom $(\mathrm{df})=19$, the value of $t$-test $=30.117$. Thus, the value of t-test was higher than the t-table $(30.117>2.093)$. It means that after delivering mobile learning there is a significant difference between the students ' pre-test and post-test in vocabulary. It can also be inferred that the null hypothesis (H0) has been rejected and the alternative (H1) has been accepted.

From the analysis above, the researchers concluded that there was a significant difference between the score that the students got from pre-test and post-test after using mobile learning. It can be concluded that the use of mobile learning in teaching vocabulary was significantly increasing the students' vocabulary achievement. 


\section{Discussion}

The students were active and enjoyed the process of teaching and learning. By using smartphones, they demonstrated their enthusiasm and interest in learning vocabulary. Consequently, almost all the students took part in the teaching and learning process.

The students' vocabulary ability before treatment on average gets a very poor classification. Moreover, the ability of students after treatment on average gets a fair classification and good classification. It means that the application of using mobile learning in teaching and learning vocabulary could increase the students' achievement from classification scores is very poor to good classification scores.

The description of the data collected in the previous section through the vocabulary test shows that the English vocabulary of the participants is increasing. It has been confirmed by the frequency and performance percentage of the pre-test and post-test. The students' score after giving treatment by using mobile learning in teaching and learning vocabulary was better before the treatment given to them.

Based on the data analysis where it shows that there was a significant difference of the students' vocabulary mastery before and after using mobile learning in the teaching and learning process, it can be considered that mobile learning was effective significantly on the effectiveness of students' vocabulary learning. This finding is in line with some previous researches who studied about the use of mobile learning [10]; [11]; [12], [13]; [14]; [3].

Some factors cause the increase of the students' scores from the pre-test to the posttest by using mobile learning. First, the teaching strategy was suitable for the level of students, and they were allowed to learn with using the smartphone, most of them involved themselves in learning process actively, and also they worked together to overcome the problem, that was to seek the meaning of the vocabulary given.

The researcher proposed that there were weaknesses and the strengths of using mobile learning in teaching and learning vocabulary. During the treatment, the class was noisy. The use of mobile learning probably caused it, and they learned that while they use smartphones. Besides, the time required in applying mobile learning in the teaching and learning process was lengthy. However, this problem can be solved by applying mobile learning outside the classroom. Mobile phones play a vital role in expanding learning anywhere in the classroom [15].

On the other side, mobile learning is learning that can increase student learning outcomes and provide broad opportunities for students to interact with teachers directly and create active and meaningful learning situations for students about vocabulary material, optimizing activities in learning involving all students in learning in class. The mobile learning application makes students enjoy learning directly from their Android smartphone so that students do not only have extensive vocabulary material in class but can also do it anywhere and anytime. Mobile learning could attract students' interest and encourage students' motivation. Furthermore, Mobile learning refers to the use of mobile devices as a tool or cognitive machine to facilitate higherorder thinking skills [16]. 


\section{Conclusion}

Based on the findings, the researcher would come to a conclusion. Mobile learning is effective in teaching English vocabulary to SMP Batara Gowa seventh grade students in academic years 2018/2019 as it can be seen through pre-test and post-test results. Students post-test are higher than the pre-test results. The seventh-grade students of SMP Batara Gowa were just in "very poor" category in the pre-test. The seventh-grade students of SMP Batara Gowa were "fair" category in the post-test. It assumes that the use of mobile learning in the teaching of English vocabulary can enable students in the learning process and improve student learning outcomes so that the application of this strategy was suitable and effective in students' English vocabulary mastery.

\section{References}

[1] Dočekal, V., \& Tulinská, H. (2015). The Impact of Technology on Education Theory. Procedia - Social and Behavioral Sciences, 174, 3765-3771. https://doi.org/10.1016/j.sbs pro.2015.01.1111

[2] Dong, C., \& Liu, X. (2013). Development of Android Application for Language Studies. IERI Procedia, 4, 8-16. https://doi.org/10.1016/j.ieri.2013.11.003

[3] Wu, Q. (2015). Designing a smartphone app to teach English (L2) vocabulary. Computers \& Education, 85, 170-179. https://doi.org/10.1016/j.compedu.2015.02.013

[4] Pilar, R.-A., Jorge, A., \& Cristina, C. (2013). The Use of Current Mobile Learning Applications in EFL. Procedia - Social and Behavioral Sciences, 103, 1189-1196. https:// doi.org/10.1016/j.sbspro.2013.10.446

[5] Matthews, J. (2018). Vocabulary for listening: Emerging evidence for high and midfrequency vocabulary knowledge. System, 72, 23-36. https://doi.org/10.1016/j.system.20 17.10 .005

[6] Şen, Y., \& Kuleli, M. (2015). The Effect of Vocabulary Size and Vocabulary Depth on Reading in EFL Context. Procedia - Social and Behavioral Sciences, 199, 555-562. https: //doi.org/10.1016/j.sbspro.2015.07.546

[7] Gairns, R., \& Redman, S. (1986). Working with words: A guide to teaching and learning vocabulary. Cambridge University Press Cambridge.

[8] Sedgwick, T. (1840). A collection of the political writings of William Leggett.

[9] Gay, L. R. (1981). Educational Research-: Charles E. Merill Columbus Ohio.

[10] Agca, R. K., \& Özdemir, S. (2013). Foreign Language Vocabulary Learning with Mobile Technologies. Procedia - Social and Behavioral Sciences, 83, 781-785. https://doi.org/10. 1016/j.sbspro.2013.06.147

[11] Hao, Y., Lee, K. S., Chen, S.-T., \& Sim, S. C. (2019). An evaluative study of a mobile application for middle school students struggling with English vocabulary learning. Computers in Human Behavior, 95, 208-216. https://doi.org/10.1016/j.chb.2018.10.013

[12] Mahande, R. D., \& Jasruddin. (2018). Utilisation Study of Mobile Technology at a Vocational High School [Preprint]. doi: 10.31227/osf.io/52pg8

[13] Nikoopour, J., \& Kazemi, A. (2014). Vocabulary Learning through Digitized \& Nondigitized Flashcards Delivery. Procedia - Social and Behavioral Sciences, 98, 1366-1373. https://doi.org/10.1016/j.sbspro.2014.03.554 
[14] Tsai, Y.-L., \& Tsai, C.-C. (2018). Digital game-based second-language vocabulary learning and conditions of research designs: A meta-analysis study. Computers \& Education, 125, 345-357. https://doi.org/10.1016/j.compedu.2018.06.020

[15] Rahimi, M., \& Miri, S. S. (2014). The Impact of Mobile Dictionary Use on Language Learning. Procedia - Social and Behavioral Sciences, 98, 1469-1474. https://doi.org/10.10 16/j.sbspro.2014.03.567

[16] Hamdani, D. S. A. (2013). Mobile Learning: A Good Practice. Procedia - Social and Behavioral Sciences, 103, 665-674. https://doi.org/10.1016/j.sbspro.2013.10.386

\section{Authors}

Iriany Kesuma Wijaya is the head of STKIP YPUP Makassar, South Sulawesi Indonesia. She is also a lecturer on Instructional Media on ELT. She has researched on Downloading Music: Pertuturan Ditinjau Dengan Pendekatan Analisis Percakapan.

Rina Asrini Bakri is the head of English Study Program STKIP YPUP Makassar. She has conducted a research entitiled The Correlation Between Frequency of Watching English Movies and Vocabulary Mastery.

Antonius Ali Wutun is the head of research institute and community service STKIP YPUP Makassar. He has some researches about teaching English including:

1. Integrating Local Culture in English language Teaching to Triger Students to Speak in English

2. Local Cultural Contents and Learners' Characteristics in Foreign Language Learning

3. Local Culture in English Language Teaching: Learners' Perspectives.

Fitriani is a lecturer on Project on IT on ELT and Instructional Media. She is the Editor team of the Celebes Education Review Journal.

Achsan Andi Mattoliang is a student of STKIP YPUP Makassar, Indonesia.

Article submitted 2019-06-30. Resubmitted 2019-10-29. Final acceptance 2019-10-30. Final version published as submitted by the authors. 